\title{
Dystrophic mineralization in uremic dogs: an update ${ }^{1}$
}

\author{
Paula G.S. Cardoso ${ }^{2}$ (D), Marcela P.R. Pinto², Ludmila R. Moroz ${ }^{3}$ (D), \\ Thanielle N. Fontes ${ }^{2}$, Rosilane S. Santos ${ }^{4}$, Júlia L. Freitas ${ }^{2}$, Vivian A. Nogueira ${ }^{5}$ \\ and Tiago C. Peixoto ${ }^{3 *}$ (D)
}

\begin{abstract}
Cardoso P.G.S., Pinto M.P.R., Moroz, L.R., Fontes T.N., Santos R.S., Freitas J.L., Nogueira V.A. \& Peixoto T.C. 2019. Dystrophic mineralization in uremic dogs: an update. Pesquisa Veterinária Brasileira 39(11):889-899. Departamento de Anatomia, Patologia e Clínicas Veterinárias, Universidade Federal da Bahia, Avenida Adhemar de Barros 500, Ondina, Salvador, BA 40170-110, Brazil. E-mail: tcpeixoto@ufba.br

Pathological mineralization is the abnormal deposition of minerals in body tissues, previously injured or not. In these lesions, in addition to calcium, other minerals can be found at lower concentrations. Classically, mineralization is divided into two types: dystrophic and metastatic. However, currently, there is no consensus among researchers on the type of mineralization that occurs in uremic dogs. The objective of this study was to elucidate the type of pathological mineralization that occurs in dogs with uremic syndrome through the correlation of biochemical examinations with gross and histopathological changes, given the existence of controversial information on this theme in the specialized literature. The Shapiro-Wilk, D'Agostino and Pearson tests were used to evaluate data normality distribution, and analysis of variance (ANOVA) was applied to compare the data between more than two groups. Additionally, the Dunnett's multiple comparison test was used in the comparison between the Control Group (CG) and the Experimental Groups (G1, G2, and G3). Serum levels of urea, creatinine, total and ionized calcium, phosphorus, calcium-phosphorus product (CPP), parathyroid hormone (PTH), and albumin of 40 azotemic dogs with chronic kidney disease (CKD) were evaluated. Dogs were categorized by degree of azotemia (mild, moderate, and severe). Ionized hypocalcemia was observed in $97.5 \%$ (39/40) of the dogs, and no animals presented ionized hypercalcemia. Hyperphosphatemia was frequent (62.5\%), especially in dogs with severe azotemia. PTH concentration increased with progression of azotemia, and high PTH levels were verified in 100\% of the dogs with severe azotemia. CPP $>60 \mathrm{mg}^{2} / \mathrm{dl}^{2}$ was observed in $75 \%$ (30/40) of the dogs. Of the 29 dogs that died during the study period, 16 were necropsied. Soft tissue mineralization was observed in $93.7 \%$ $(15 / 16)$ of these dogs at gross and histopathological evaluation (HE and Von Kossa), regardless of the degree of azotemia, in nine organs/tissues: kidneys (75\%), lungs (50\%), stomach (31.2\%), heart (25\%), larynx (25\%), intercostal muscles (25\%), aorta (6.2\%), intestines (6.2\%), and tongue (6.2\%). In one animal, the serosa of all segments of the small intestine showed whitish, rough, irregular, multifocal plaques of varying sizes, confirmed by histopathology as dystrophic mineralization of the longitudinal outer muscular layer, which presented necrosis of coagulation and of the intestinal serosa. This intestinal lesion has not been described in dogs with uremic syndrome to date. In conclusion, the laboratory and histopathologic data previously described, especially regarding tissue and vascular mineralization, which occur in association with previous degenerative/necrotic lesions in the absence of hypercalcemia in dogs with CKD, assist with clarifying inconsistencies found in the existing literature. Therefore, conceptually, mineralization that occurs in uremic dogs should be considered dystrophic.
\end{abstract}

INDEX TERMS: Dystrophy, mineralization, uremia, dogs, nephrology, pathological mineralization.

\footnotetext{
${ }^{1}$ Received on June 17, 2019.

Accepted for publication on July 17, 2019.

Part of Master's Thesis of the first author.

${ }^{2}$ Graduate Studies Program in Animal Science in the Tropics (PPGCAT), Escola de Medicina Veterinária e Zootecnia (EMEVZ), Universidade Federal da Bahia (UFBA), Salvador, BA 40170-110, Brazil.

${ }^{3}$ Departamento de Anatomia, Patologia e Clínicas Veterinárias, Escola de
}

\footnotetext{
Medicina Veterinária e Zootecnia (EMEVZ), Universidade Federal da Bahia (UFBA), Salvador, BA 40170-110. ${ }^{*}$ Corresponding author: tcpeixoto@ufba.br

${ }^{4}$ Veterinarian, Salvador, BA, Brazil.

${ }^{5}$ Departamento de Epidemiologia e Saúde Pública, Instituto de Veterinária, Universidade Federal Rural do Rio de Janeiro (UFRRJ), Rodovia BR-465 Km 7, Seropédica, RJ 23890-000, Brazil.
} 
RESUMO.- [Mineralização distrófica em cães urêmicos: uma atualização.] Mineralização patológica é a deposição anormal de minerais em tecidos previamente lesados ou não. Nessas lesões, além do cálcio, outros minerais podem ser encontrados em concentrações inferiores. Classicamente, as mineralizações são divididas em dois tipos: distrófica e metastática. Contudo, atualmente, ainda não há consenso entre os pesquisadores sobre o tipo de mineralização que ocorre em cães urêmicos. Objetivou-se com esse estudo elucidar o tipo de mineralização patológica que ocorre em cães com síndrome urêmica através da correlação de exames bioquímicos com alterações macroscópicas e histopatológicas, visto a existência de informações controversas na literatura especializada. Os dados obtidos foram submetidos ao teste de Shapiro-Wilk e teste de D'Agostino e Pearson para avaliação da normalidade da distribuição e para comparação de dados em mais de dois grupos foi utilizado o teste ANOVA. Adicionalmente, o teste de comparações múltiplas de Dunnett permitiu a comparação entre o grupo controle (GC) com os demais grupos (G1, G2 e G3). Foram avaliados os níveis séricos de ureia, creatinina, cálcio total e ionizado, fósforo, produto cálcio-fósforo (PCF), PTH e albumina de 40 cães azotêmicos com doença renal crônica (DRC). Os cães foram classificados quanto ao grau de azotemia (leve, moderada e severa). Verificou-se hipocalcemia ionizada em 97,5\% (39/40) dos cães e, em nenhum animal houve hipercalcemia ionizada. Hiperfosfatemia foi frequente $(62,5 \%)$, principalmente em cães com azotemia severa. A concentração do PTH aumentou conforme a progressão da azotemia, encontrando-se elevada em $100 \%$ dos cães com azotemia severa. Em 75\% (30/40) dos cães o PCF foi superior a $60 \mathrm{mg}^{2} / \mathrm{dl}^{2}$. Durante o estudo, 29 cães morreram, sendo 16 desses necropsiados. Em 93,7\% $(15 / 16)$ desses cães observou-se mineralização de tecidos moles, durante a avaliação macroscópica e histopatológica (HE e Von Kossa), independentemente do grau de azotemia, em nove órgãos/tecidos: rins (75\%), pulmões (50\%), estômago $(31,2 \%)$, coração $(25 \%)$, laringe $(25 \%)$, músculos intercostais $(25 \%)$, aorta $(6,2 \%)$, intestino $(6,2 \%)$ e língua $(6,2 \%)$. Adicionalmente, em um animal verificou-se na serosa de todos os segmentos do intestino delgado placas multifocais brancacentas, rugosas, irregulares de tamanhos variados, cuja histopatologia confirmou tratar-se de mineralização distrófica da camada longitudinal muscular externa que apresentava necrose de coagulação e da serosa intestinal. Essa lesão intestinal nunca havia sido descrita em cães com síndrome urêmica. Em suma, os dados laboratoriais e histopatológicos aqui descritos, sobretudo, no que se refere à mineralização tecidual e vascular, que ocorrem relacionadas a lesões degenerativo-necróticas prévias, na ausência de hipercalcemia, em cães com DRC, ajudam a esclarecer as incongruências existentes na literatura. Por conseguinte, conceitualmente, as mineralizações que ocorrem em cães urêmicos devem ser consideradas distróficas.

TERMOS DE INDEXAÇÃO: Mineralização, distrofia, cães, uremia, caninos, nefrologia, mineralização patológica.

\section{INTRODUCTION}

Pathological mineralization is the abnormal deposition of minerals in body tissues, whether previously or injured not. In these lesions, in addition to calcium, other minerals such as iron, magnesium, and phosphorus can be found at lower concentrations. Classically, mineralization is divided into two types: dystrophic and metastatic. The dystrophic type occurs when there is deposition of minerals in tissues previously affected by lesions of necrotic, degenerative or inflammatory nature, regardless of serum calcium concentration (Peixoto et al. 2012, Doerr et al. 2013), whereas the metastatic type is characterized by precipitation of calcium salts in tissues due to persistently high serum calcium concentration with no previous tissue injury (Doerr et al. 2013, Foster 2016). However, Peixoto et al. (2012) have recently demonstrated that mineralization that occurs in soft tissues of animals intoxicated by vitamin $\mathrm{D}$ or calcinogenic plants should not be considered metastatic, as described in most textbooks, because in essence there is a tissue modification characteristic of metaplasia. Thus, Peixoto and collaborators proposed that this particular type of hormone-induced mineralization (vitamin D) should be more appropriately termed either mineralization over or by metaplasia, or simply metaplastic mineralization. Additionally, Peixoto et al. (2012) stated that there are still many gaps regarding the interaction that occurs between the hormones involved in physiological and pathological mineralization, and that descriptions are generic and inaccurate, which make the understanding of these phenomena even more difficult.

Currently, there is no consensus among researchers regarding the type of pathological mineralization that occurs in dogs with uremia. According to the national and international literature specialized in veterinary pathology, uremia-associated soft tissue mineralization represents both the metastatic and dystrophic types (Santos 1979, Confer \& Panciera 1998, Cheville 2004, Newman 2013). In contrast, Jones et al. (2000) stated that metastatic mineralization occurs in uremia and Cheville (2004) recognized that hypercalcemia can rarely be directly associated with tissue calcification, but claimed that uremia is one of the most common causes of metastatic mineralization. However, according to Serakides (2011), soft tissue mineralization is dystrophic, because it is preceded by degenerative changes induced by toxins accumulated in the bloodstream, such as creatinine, ammonia, and parathyroid hormone (PTH), as well as by the absence of hypercalcemia (a condition necessary for metastatic mineralization to occur). Such textbooks, published until the present decade, have been adopted as primary literature in veterinary schools in Brazil.

Although there are several studies addressing necroscopic and histopathologic lesions in dogs with chronic kidney disease (CKD) (Cheville 1979, Dantas \& Kommers 1997, Peters et al. 2005, Inkelmann et al. 2012, Silveira et al. 2015) in the literature, they do not correlate these lesions with serum calcium, phosphorus and PTH levels, which could better support discussion on the pathogenesis of pathological mineralization in the soft tissue of dogs with uremic syndrome. Thus, the objective of this study was to elucidate or provide subsidies to establish the type of pathological mineralization that occurs in uremic dogs.

\section{MATERIALS AND METHODS}

The present study was conducted at the "Hospital de Medicina Veterinária Renato de Medeiros Netto" (HOSPMEV), "Universidade Federal da Bahia" (UFBA), and at the Hospital of the Department of Veterinary Medicine (HOVET- DMV), "Universidade Federal Rural de Pernambuco" (FRPE). The study sample was composed of 40 dogs, 
regardless of breed, age or gender, included in the routine assistance to small animals of HOSPMEV-UFBA and HOVET-UFRPE from December 2016 to August 2018, with clinical history and laboratory changes compatible with chronic kidney disease (CKD) (inclusion criteria: renal azotemia - creatinine $\geq 1.4 \mathrm{mg} / \mathrm{dL}$-, persistent for at least three months, or two measurements).

The selected dogs were divided into three experimental groups according to serum creatinine value: G1 (mild azotemia, 1.4-2.0 mg/dl), G2 (moderate azotemia, 2.1-5.0mg/dl) and G3 (severe azotemia, $>5.0 \mathrm{mg} / \mathrm{dl}$ ) using the same creatinine criteria of the IRIS staging system (IRIS 2017). Eight healthy dogs comprised the Control Group (CG). The term CKD was adopted to describe the nephropathy diagnosed in dogs of the three experimental groups, that is, it ranged from the initial and asymptomatic stages to the final stages of the disease (chronic renal failure and renal failure), according to the terminologies proposed by Romão Junior (2004) and Polzin (2008).

This study followed the norms for animal use and experimentation and was approved by the Animal Use Ethics Committee (CEUA) of the UFBA College of Veterinary Medicine and Zootechnics (EMEVZ) under protocol no. 75/2016, and only dogs with CKD whose guardians signed an Informed Consent Form (ICF) were included in the experimental groups. Dogs with urinary tract obstruction (post-renal azotemia), primary or nutritional hyperparathyroidism, hypoparathyroidism, hypercortisolinism, intoxication, neoplasms, malignancy (paraneoplastic) hypercalcemia or non-azotemic CKD were excluded from the study.

Blood samples were collected via puncture of the jugular, cephalic or femoral vein. Serum for biochemical analysis was obtained after clot retraction of the samples in tubes without anticoagulant. It was centrifuged at $3000 \mathrm{rpm}$ for $5 \mathrm{~min}$ and then placed in $2.0 \mathrm{ml}$ polypropylene tubes. Serum urea, creatinine, and phosphorus measurements were performed at the Clinical Analysis Laboratory (LAC) at UFBA using the following methods: enzyme kinetic assay (urea), enzymatic colorimetric assay (creatinine), and colorimetric assay (phosphorus). Calcium and albumin measurements (colorimetric method) were performed at the Laboratory of Nutritional and Metabolic Diseases at UFRPE. When serum albumin values were $<3.5 \mathrm{mg} / \mathrm{dl}$, total calcium (Cat) to corrected calcium (Cac) was corrected according to the formula [Cac = (Cat - serum albumin) +3.5], proposed by Chew \& Meuten (1982). Ionized calcium (Cai) concentration was determined by the ion-selective electrode method using a gas analyzer (Cobas b 121 Analyzer). The calcium-phosphorus product (CPP) was calculated by multiplying the corrected calcium and phosphorus serum concentrations. CPP values $<60 \mathrm{mg}^{2} / \mathrm{dl}^{2}$ were considered normal and $\geq 60 \mathrm{mg}^{2} / \mathrm{dl}^{2}$ were considered abnormal, according to Mcleland et al. (2014).

For determination of parathyroid hormone (PTH), whole blood samples packed in a dry tube were centrifuged at 1900rpm for $10 \mathrm{~min}$ in a $4^{\circ} \mathrm{C}$ refrigerated centrifuge to obtain at least $1.0 \mathrm{ml}$ of serum. After centrifugation, the serum was packed in light-protected $2 \mathrm{ml}$ polypropylene tubes and frozen at $-80^{\circ} \mathrm{C}$ (Schenck et al. 2007) until examination. Intact PTH concentrations were determined by an enzyme-linked immunosorbent assay (ELISA) (Canine Intact PTH, Immutopics, Inc., San Clemente, California, USA) previously validated in dogs (Kilpatrick et al. 2015). Reading was performed using a $450 \mathrm{~nm}$ wavelength spectrophotometer.

After the death, or euthanasia in extremis of dogs with CKD, when authorized by the guardians, the animals were sent to the Veterinary Pathology Laboratory (LPV) at UFBA for necropsy. Euthanasia in extremis was performed in CKD terminal phase animals.
The guardians opted for this procedure in case of unfavorable prognosis. During necropsy, fragments of organs of the abdominal and thoracic cavities, bones, and brain were collected and fixed in buffered formalin. Additionally, the bones were decalcified in formic acid. After fixation, the material was cleaved, routinely processed for histology, and stained with hematoxylin and eosin (HE) and special Von Kossa.

The data obtained were tabulated and collected in an orderly manner. A $p$ value $<0.05$ was considered significant. The Shapiro-Wilk, D'Agostino and Pearson tests were used to evaluate data normality distribution, and analysis of variance (ANOVA) was applied to compare the data between more than two groups. The Dunnett's multiple comparison test was used in the comparison between the Control Group (CG) and the Experimental Groups (G1, G2, and G3).

\section{RESULTS}

The 40 dogs with chronic kidney disease (CKD) were divided into groups according to the following degrees of azotemia observed at the time of diagnosis: 15 , mild (G1); 10, moderate (G2); 15, severe (G3). Table 1 shows the main biochemical changes found.

Hyperphosphatemia was common (62.5\%, 25/40) in dogs with CKD, and serum phosphorus concentration severely increased as azotemia progressed, which was high in $26.6 \%$ in G1 (4/15 dogs, mean=5.1mg/dl), 70\% in G2 (7/10 dogs, mean=8.1mg/dl), and 93.8\% in G3 (14/15 dogs, mean $=17.5 \mathrm{mg} / \mathrm{dl})$. No statistically significant differences in mineral concentration were verified when the G1 and G2 were compared with the CG, but dogs with severe azotemia (G3) presented higher phosphorus values than those of dogs in the other groups $(p<0.0001)$.

No statistically significant differences were observed in total corrected calcium (Cac) concentrations in the comparison between the CG and the experimental groups ( $p=0.07)$, with means of $9.4,11.2,10.1$ and $9.9 \mathrm{mg} / \mathrm{dl}$ in dogs from the GC, G1, G2 and G3, respectively. Cai was below normal level in $97.5 \%$ (39/40) of the dogs (mean: $\mathrm{CG}=5.0 \mathrm{mg} / \mathrm{dl}, \mathrm{G} 1=3.5 \mathrm{mg} / \mathrm{dl}$, $\mathrm{G} 2=2.7 \mathrm{mg} / \mathrm{dl}$ and G3=2.2mg/dl). All dogs in G1 and G3 had ionized hypocalcemia. In G2, nine (90\%) dogs had reduced Cai, and only one animal (10\%) presented normocalcemia. The serum Cai concentrations observed in dogs of the three experimental groups significantly differed from those of dogs in the CG $(p<0.0001)$.

Among the 40 dogs with CKD, only 10 [25\% (10/40)] had calcium-phosphorus product (CPP) values $<60 \mathrm{mg}^{2} / \mathrm{dl}^{2}$ : nine in G1 and one in G2. The average CPP values were 161.8, 79.0, 57.8 and $36.74 \mathrm{mg}^{2} / \mathrm{dl}^{2}$ in G3, G2, G1 and GC, respectively. Statistically significant differences in $\mathrm{CPP}$ values were observed in the comparison between CG and G3 $(p<0.0001)$.

Parathyroid hormone (PTH) concentration increased as azotemia progressed, and was high in $73.3 \%$ of the dogs in G1 (11/15), 80\% in G2 (8/10) and 100\% in G3 (15/15). The following average values were found: $102.4 \mathrm{pg} / \mathrm{ml}$ in G1, $145.4 \mathrm{pg} / \mathrm{ml}$ in $\mathrm{G} 2$ and $551.3 \mathrm{pg} / \mathrm{ml}$ in G3, and statistically significant differences were verified in the comparison of PTH values between G1 and G2 with G3 $(p<0.0001)$. Statistically significant difference was also observed when the PTH reference value of healthy animals was compared with those of dogs in the three experimental groups $(p<0.01)$.

Twenty-nine dogs $(72.5 \%, 29 / 40)$ had a fatal outcome during the study, 15 (51.7\%) due to natural death, and 14 
(48.3\%) undergoing euthanasia in extremis. Of the 16 necropsied dogs (40\%), one belonged to G1, six to G2 and nine to G3. Extrarenal lesions of uremia are described ahead in order of frequency and presented in Table 2 .

Both kidneys of each of the 16 necropsied dogs (32 kidneys) had severe gross (Fig.1A) and histologic lesions. In general, there was pallor, size reduction, uneven surface with occasional retention cysts, fibrosis, mineralization, and parenchyma retraction. Nephrosis was observed in 12 (75\%) dogs, infarction areas was verified in 11 (68.7\%) animals, retention cysts was found in seven (43.7\%) dogs, and hydronephrosis was observed in only two (12.5\%) animals.
The main renal lesions responsible for uremia and extrarenal lesions of the uremic syndrome were chronic interstitial nephritis $(56.2 \%, 9 / 16)$, tubular nephrosis associated with chronic interstitial nephritis $(18.7 \%, 3 / 16)$, glomerulosclerosis $(6.2 \%, 1 / 16)$, fibrosis associated with chronic renal infarction $(6.2 \%, 1 / 16)$, glomerulonephritis associated with interstitial nephritis $(6.2 \%, 1 / 16)$, and progressive juvenile nephropathy $(6.2 \%, 1 / 16)$. Histopathologic examination revealed changes such as interstitial nephritis (100\%, 16/16), hyalinization and thickening of the Bowman's capsule $(87.5 \%, 14 / 16)$, renal tubular ectasia $(87.5 \%, 14 / 16)$, interstitial fibrosis $(68.7 \%, 11 / 16)$, hyaline cylinder formation $(68.7 \%, 11 / 16)$,

Table 1. Mean values, standard deviation and range of serum urea, creatinine, phosphorus, ionized calcium (Cai), calcium-phosphorus product (CPP) and PTH of the 40 dogs in the experimental and control groups, distributed according to degree of azotemia

\begin{tabular}{|c|c|c|c|c|c|}
\hline \multirow[b]{2}{*}{ Variables } & & \multirow{2}{*}{$\begin{array}{l}\text { Control Group } \\
(n=10)\end{array}$} & \multicolumn{3}{|c|}{ Degree of azotemia } \\
\hline & & & $\begin{array}{l}\text { Group 1 } \\
(n=15)\end{array}$ & $\begin{array}{l}\text { Group } 2 \\
(n=10)\end{array}$ & $\begin{array}{l}\text { Group } 3 \\
(n=15) \\
\end{array}$ \\
\hline Creatinine $(\mathrm{mg} / \mathrm{dL})$ & $\begin{array}{l}\text { Mean } \pm \mathrm{SD}^{c} \\
\text { Interval }\end{array}$ & $\begin{array}{c}0.8 \pm 0.3 \\
(0.4-1.1)\end{array}$ & $\begin{array}{l}1.7 \pm 0.2 \\
(1.4-2)\end{array}$ & $\begin{array}{c}3.5 \pm 0.8^{\mathrm{a}} \\
(2.5-4.7)\end{array}$ & $\begin{array}{c}9.8 \pm 3.7^{\mathrm{a}} \\
(5.5-18.8)\end{array}$ \\
\hline Urea $(\mathrm{mg} / \mathrm{dL})$ & $\begin{array}{l}\text { Mean } \pm \text { SD } \\
\text { Interval }\end{array}$ & $\begin{array}{c}28.8 \pm 10.3 \\
(15.7-41.2)\end{array}$ & $\begin{array}{c}86.5 \pm 44.2 \\
(28.7-302.2)\end{array}$ & $\begin{array}{c}175 \pm 107.2^{\mathrm{a}} \\
(64-406)\end{array}$ & $\begin{array}{c}378.9 \pm 133.3^{\mathrm{a}} \\
(238-646)\end{array}$ \\
\hline Phosphorus (mg/dL) & $\begin{array}{l}\text { Mean } \pm \text { SD } \\
\text { Interval }\end{array}$ & $\begin{array}{c}3.9 \pm 1.4 \\
(2.1-5.7)\end{array}$ & $\begin{array}{c}5.1 \pm 1.3 \\
(3.6-10)\end{array}$ & $\begin{array}{c}8.1 \pm 2.9 \\
(2.8-11.7)\end{array}$ & $\begin{array}{c}17.5 \pm 7.6^{a} \\
(5.5-27.4)\end{array}$ \\
\hline $\mathrm{CPP}\left(\mathrm{mg}^{2} / \mathrm{dl}^{2}\right)$ & $\begin{array}{l}\text { Mean } \pm \text { SD } \\
\text { Interval }\end{array}$ & $\begin{array}{c}36.7 \pm 13.0 \\
(18.2-52.7)\end{array}$ & $\begin{array}{c}57.8 \pm 14.8 \\
(41.9-107)\end{array}$ & $\begin{array}{c}79 \pm 26.1 \\
(31.5-129.9)\end{array}$ & $\begin{array}{l}161.8 \pm 58.5^{a} \\
(73-247.6)\end{array}$ \\
\hline PTH (pg/ml) & $\begin{array}{l}\text { Mean } \pm \text { SD } \\
\text { Interval }\end{array}$ & $\mathrm{ND}^{\mathrm{d}}$ & $\begin{array}{c}102.4 \pm 65.1^{\mathrm{b}} \\
(20.2-213.2)\end{array}$ & $\begin{array}{l}145.4 \pm 103.8^{b} \\
(15.4-356.2)\end{array}$ & $\begin{array}{c}551.3 \pm 311.8^{\mathrm{b}} \\
(121.4-1201)\end{array}$ \\
\hline
\end{tabular}

a Statistically significant differences compared with healthy dogs, ${ }^{\mathrm{b}}$ statistically significant differences compared with the reference value for healthy dogs,

${ }^{\mathrm{c}} \mathrm{SD}=$ standard deviation, ${ }^{\mathrm{d}} \mathrm{ND}=$ not determined.

Table 2. Frequency of extrarenal lesions of uremia in 16 dogs with chronic kidney disease (CKD)

\begin{tabular}{|c|c|c|}
\hline Lesion & Dogs & Frequency $(\%)$ \\
\hline Uremic lung disease & $6,8,10,12,13,17,18,26,29,32,33,34,35,37,39$, and 40 & $100 \%(16 / 16)$ \\
\hline Stained mucous membranes (anemia) & $6,8,10,12,17,18,26,29,32,33,34,35,37,39$, and 40 & $93.7 \%(15 / 16)$ \\
\hline Uremic gastropathy & $6,8,10,12,13,17,18,26,29,33,34,35,37,39$, and 40 & $93.7 \%(15 / 16)$ \\
\hline Soft tissue mineralization: & & $93.7 \%(15 / 16)$ \\
\hline Kidneys $^{\mathrm{a}}$ & $6,8,10,12,18,26,29,34,35,37,39$, and 40 & $75 \%(12 / 16)$ \\
\hline Larynx & $6,10,17,18,32,33,35$, and 40 & $50 \%(8 / 16)$ \\
\hline Lungs & $12,18,26,29,32,35,37$, and 40 & $50 \%(8 / 16)$ \\
\hline Stomach & $10,18,26,34,39$, and 40 & $31.2 \%(5 / 16)$ \\
\hline Heart & $6,17,18$, and 26 & $25 \%(4 / 16)$ \\
\hline Intercostal muscles & $12,17,32$, and 35 & $25 \%(4 / 16)$ \\
\hline Aorta & 18 & $6.2 \%(1 / 16)$ \\
\hline Intestines & 18 & $6.2 \%(1 / 16)$ \\
\hline Tongue & 26 & $6.2 \%(1 / 16)$ \\
\hline Arteriosclerosis & $6,12,13,17,18,26,29,32,33,34,35$, and 37 & $75 \%(12 / 16)$ \\
\hline Necrotic and ulcerative stomatitis and/or glossitis & $6,12,13,18,26,29,32,33,35,39$, and 40 & $68.7 \%(11 / 16)$ \\
\hline Uremic enteropathy & $6,10,18,26,33,34,35,37$, and 39 & $56.2 \%(9 / 16)$ \\
\hline Parathyroid hyperplasia & $6,18,26,29,33,34$, and 35 & $43.7 \%(7 / 16)$ \\
\hline Fibrinonecrotical esophagitis & 17,26 , and 35 & $18.7 \%(3 / 16)$ \\
\hline Fibrous osteodystrophy & 34 & $6.2 \%(1 / 16)$ \\
\hline Fibrinous pericarditis & 37 & $6.2 \%(1 / 16)$ \\
\hline
\end{tabular}

${ }^{a}$ Although not considered a true extrarenal lesion of uremia, as it occurs in the kidneys and secondary to CKD disorders, it has been described here. 

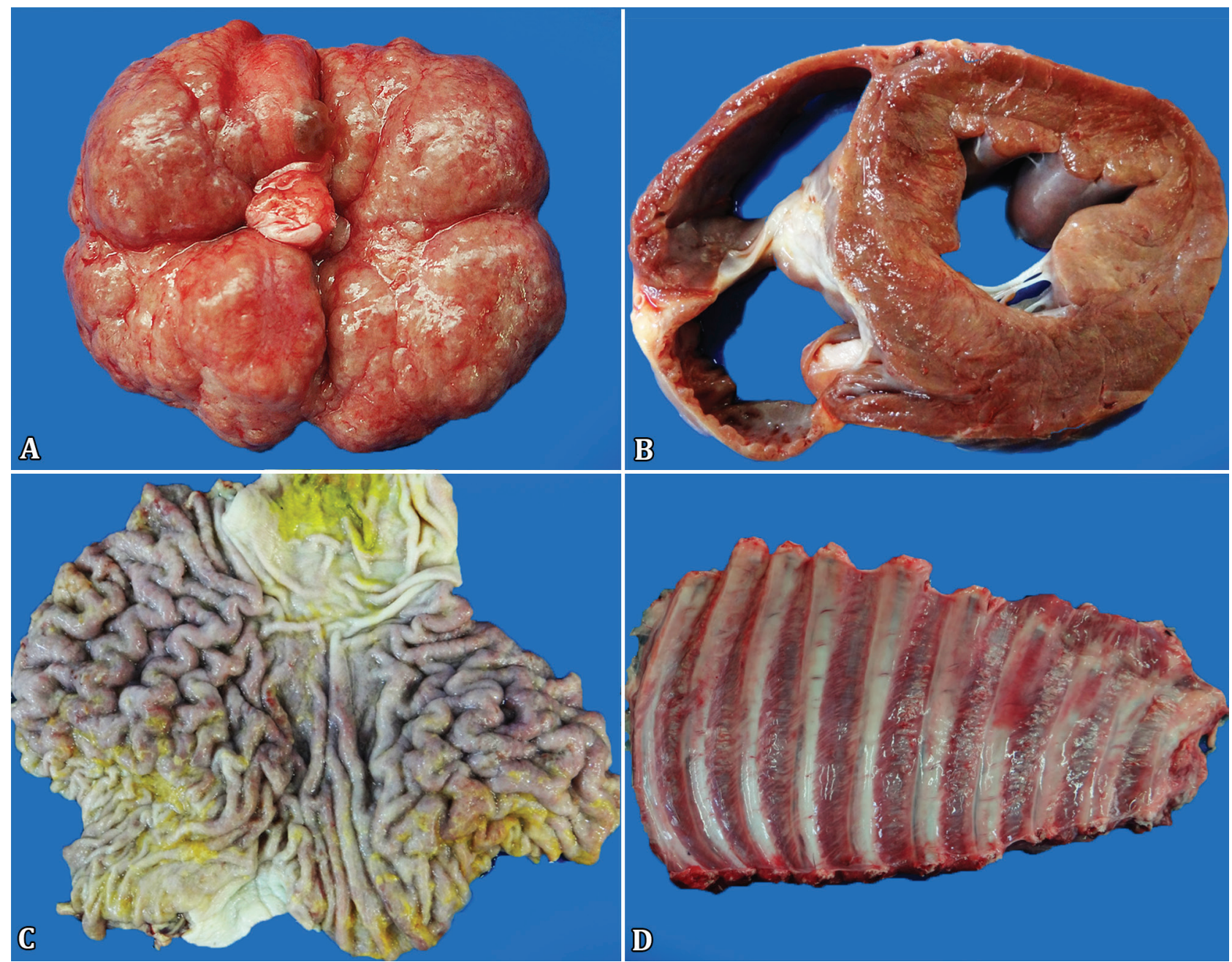

Fig.1. Chronic kidney disease (CKD) in dogs. (A) Kidney of Dog 37, G2 showing uneven natural surface and parenchyma retraction. (B) Small multifocal whitish foci in the myocardium (dystrophic mineralization). Heart of Dog 18, G3. (C) Uremic gastropathy. Marked edema and thickening of the gastric mucosal folds. Stomach of Dog 10, G3. (D) Grayish white granular pleural thickening with horizontal "scaffolding" arrangement (dystrophic mineralization). Intercostal muscle of Dog 35, G3.

glomerular atrophy $(56.2 \%, 9 / 16)$, glomerular sclerosis $(25 \%, 4 / 16)$, coagulation necrosis $(12.5 \%, 2 / 16)$ and hydropic degeneration $(12.5 \%, 2 / 16)$.

Anemia was the most frequent extrarenal lesion of uremia in this study. It was observed in all $(100 \%, 16)$ necropsied dogs, and was characterized by mild to intensely stained mucosae, organ pallor, and reduced circulating blood volume. Uremic gastropathy was observed in $93.7 \%(15 / 16)$ of the dogs, which showed erosive and/or ulcerative gastritis, edema, and hyperemia of the gastric mucosa, in addition to ammoniac odor in most cases. The gastric mucosa was mild to intensely thickened (Fig.1C) and hyperemic in 62.5\% (10/16) of the dogs in G2 and G3. Three dogs in the G3 presented gastric mucosa mineralization verified at necroscopic examination, which was confirmed by histopathology. Mineralization was observed only at histopathologic examination in only one dog in G1. Gastric content was hemorrhagic in two dogs in G3. The dogs in G2 showed loss of the gastric mucosa surface epithelium (erosion) focally, or of multifocal association with inflammatory infiltrate, predominantly lymphocytic and edematous. In the dogs in Group G3, in addition to these alterations, areas of gastric mucosa necrosis were observed, as well as mononuclear inflammatory infiltrate and multifocal hemorrhage.

Similarly, uremic pneumopathy was also observed in $15(93.7 \%)$ dogs, with pulmonary edema as the most common finding $(75 \%, 12 / 16)$. The lungs showed smooth, moist, shiny natural surface and varying amounts of free-flowing or translucent foamy fluid (edema) in the light of the bronchial and tracheal lumen. The gross and histologic lesions were compatible, and consisted of multifocal emphysema (56.2\%, $9 / 16)$, pneumonia $(37.5 \%, 6 / 16)$, congestion $(37.5 \%, 6 / 16)$, focal or multifocal atelectasis $(43.7 \%, 7 / 16)$ and hemorrhage (25\%, 4/16), in addition to edema.

In this study, soft tissue mineralization was a frequently observed change $(93.7 \%, 15 / 16)$, and involved multiple organs and tissues (Table 2). Mineralization was observed in nine different sites, namely in order of prevalence, kidneys (75\%), lungs (50\%), stomach (31.2\%), heart (25\%), larynx (25\%), intercostal muscles (25\%), aorta (6.2\%), intestines $(6.2 \%)$, and tongue $(6.2 \%)$. 
Twelve (75\%, 12/16) animals, eight of them in G3, presented mineralization in the kidneys, in some cases macroscopically visible in the form of multiple millimeter points or multifocal whitish areas. On histopathologic examination, mineralization was most commonly observed in necrotic renal tubules (coagulation necrosis) in the cortical and medullary regions. Additionally, it was verified in the glomeruli, wall of small blood vessels of the cortical region and corticomedullary junction, as well as in the Bowman's capsule (Figs.2A,B).

The lung was the second organ most affected by mineralization (50\%, 8/16) in animals in the three study groups. Lesion affected mainly the alveolar walls and, to a lesser extent, the blood vessel wall (Fig.2D). Three animals in G3 and one in G1 presented multifocal gastric mineralization, mainly in the mucosa and blood vessels, which was not macroscopically identifiable in the dog in G1.

In the heart of four $(25 \%, 4 / 16)$ animals, three in G3 and only one in $\mathrm{G} 2$, dystrophic mineralization of necrotic cardiomyocytes (hyaline coagulation necrosis) was observed (Fig.1B and 3E). Four dogs also presented mineralization of the intercostal muscles (Fig.1D), characterized by whitish, uneven and firm sandy-looking protruding areas. In four cases, irregular, whitish, firm, sandy-looking multifocal areas were found in the larynx (mineralization).

Whitish, rough, irregular, firm multifocal plaques of varying sizes (from millimeters to approximately $3.0 \mathrm{~cm}$ )were observed in the serosa of all segments of the small and large intestine in one $(6.2 \%, 1 / 16)$ dog (Fig.3). Histopathology confirmed that

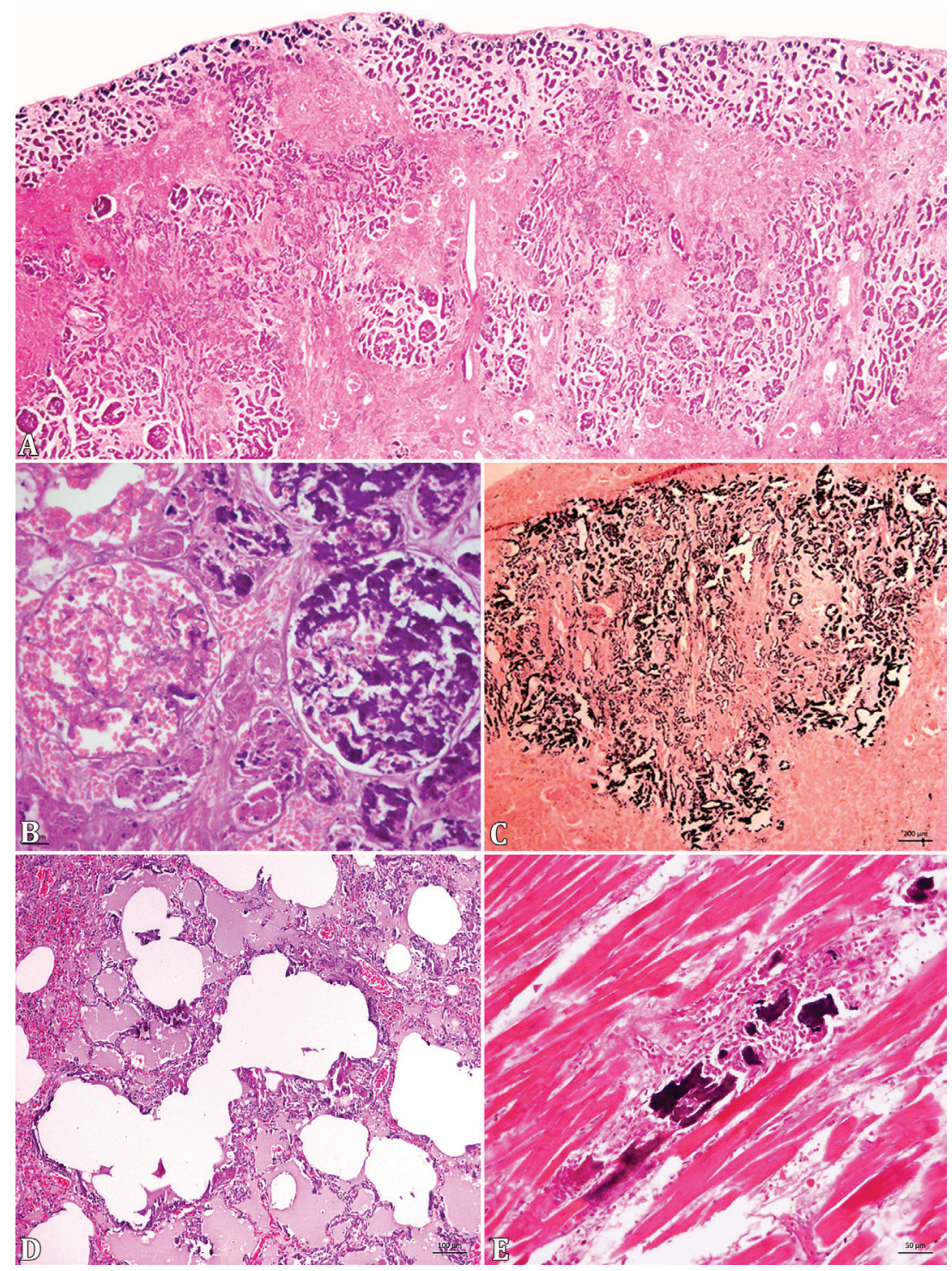

Fig.2. Dystrophic mineralization in dogs with chronic kidney disease (CKD). (A) Focal length area of dystrophic mineralization of renal glomeruli and tubules. HE, obj.5x. (B) Dystrophic mineralization of the early (left) and advanced (right) glomerular tuft associated with coagulation necrosis and renal tubule mineralization. Kidney of Dog 12, G3. HE, obj.40x. (C) Extensive areas of dystrophic mineralization of renal tubules and glomeruli (evidenced by the blackening of calcium deposits). Kidney of Dog 12, G3. Von Kossa, obj.5x. (D) Uremic lung disease. Multiple areas of dystrophic mineralization in the bronchioles, pulmonary alveolar wall, and small blood vessels associated with marked pulmonary edema. Lung of Dog 40, G2. HE, obj.10x. (E) Group of hypereosinophilic cardiomyocytes with loss of striations and foci of dystrophic mineralization over necrotic cardiomyocytes. Heart of Dog 18, G3. HE, obj.20x. 
it was dystrophic mineralization of the external longitudinal layer of the muscle that presented necrosis of coagulation and of the intestinal serosa (Fig.4A,B). Mineralization of the aorta and necrotic tongue muscle fibers were also described in only one case each.

Aortic and/or coronary arteriosclerosis was found in $12(75 \%, 12 / 16)$ dogs, five in $\mathrm{G} 2$ and seven in G3, and consisted of whitish, irregular, multifocal, plaque-shaped protruding areas in the intimal layer of the aorta that was sometimes diffusely irregular. Focal thickening was observed in the coronary arteries. Histopathologic examination revealed thickening of the tunica intima with smootvh muscle proliferation and internal elastic lamina fragmentation.

Eleven cases $(68.7 \%, 11 / 16)$ presented necrotic stomatitis and/or ulcerative glossitis: seven dogs in G3, three in G2,

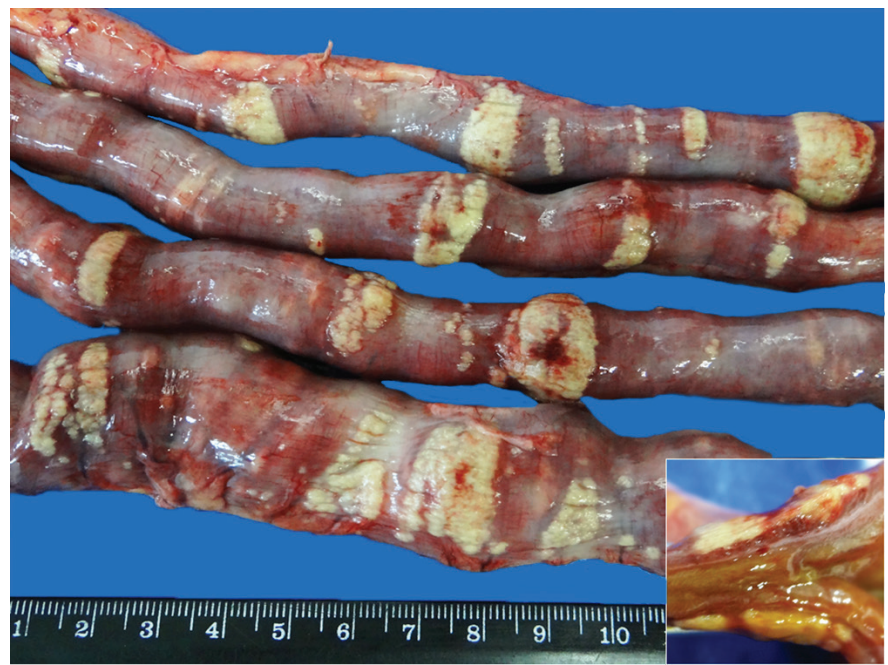

Fig.3. Chronic kidney disease (CKD) in dogs. Uremic enteropathy. Multiple irregular whitish plaques of varying sizes in the small intestine serosa that deepen into the muscular layer (detail). Accentuated multifocal dystrophic mineralization. Dog 18, G3. and one in G1. The lesions were characterized by ulcerated areas, mainly on the lateral faces or apex of the tongue and on the mouth gum, sometimes covered by necrotic tissue with hemorrhagic edges.

Uremic enteropathy was verified in nine $(56.2 \%, 9 / 16)$ dogs, eight of them belonging to G3. In these animals, there was mild, moderate or severe thickening of the intestinal wall, diffuse or multifocal, and in the case of intestinal mineralization, the wall had irregular gelatinous and serous appearance. The intestines were often reddish or blackened, and the mucosa was irregular or hyperemic. Histopathology showed, predominantly, inflammatory infiltrate, lymphoplasmacyte, congestion, and activated endothelial cells.

Bilateral parathyroid enlargement (hyperplasia) was observed in seven $(43.7 \%, 7 / 16)$ dogs, only one in G2 and six in G3. It was also verified that the seven dogs, six in G3 and one in G2, that presented parathyroid volume increase at necropsy showed high serum PTH concentrations, with values ranging from 124.2 to $1201 \mathrm{pg} / \mathrm{ml}$.

One dog in G1, two in G2 and three in G3 presented endocarditis or mural myocarditis. Atrioventricular valve endocardiosis was also found in varying degrees $(25 \%, 4 / 16)$, as well as left ventricular hypertrophy $(12.5 \%, 2 / 16)$. One animal had dilated cardiomyopathy $(6.25 \%, 1 / 16)$. Histopathologic examination generally revealed predominantly multifocal mononuclear inflammatory infiltrate associated with multifocal interstitial edema. Areas of degeneration and hyaline necrosis were also observed in the groups with cardiomyocytes $(43.7 \%, 7 / 16)$, and epicardial hemorrhage was verified in only one animal.

Fibrinonecrotic esophagitis occurred in two dogs in G3 and in one in G2 $(18.7 \%, 3 / 16)$, and fibrinous pericarditis was observed in one $(6.2 \%, 1 / 16)$ dog in $\mathrm{G} 2$.

Hyperosteotic fibrous osteodystrophy was found in only one $(6.2 \%, 1 / 16)$ dog in G3. This animal presented a significant mineralization disorder caused by intense demineralization resulting from marked bone resorption and replacement with fibrous connective tissue, which resulted in severe fragility of the maxillary and mandible bones ("rubber jaw") with bilateral
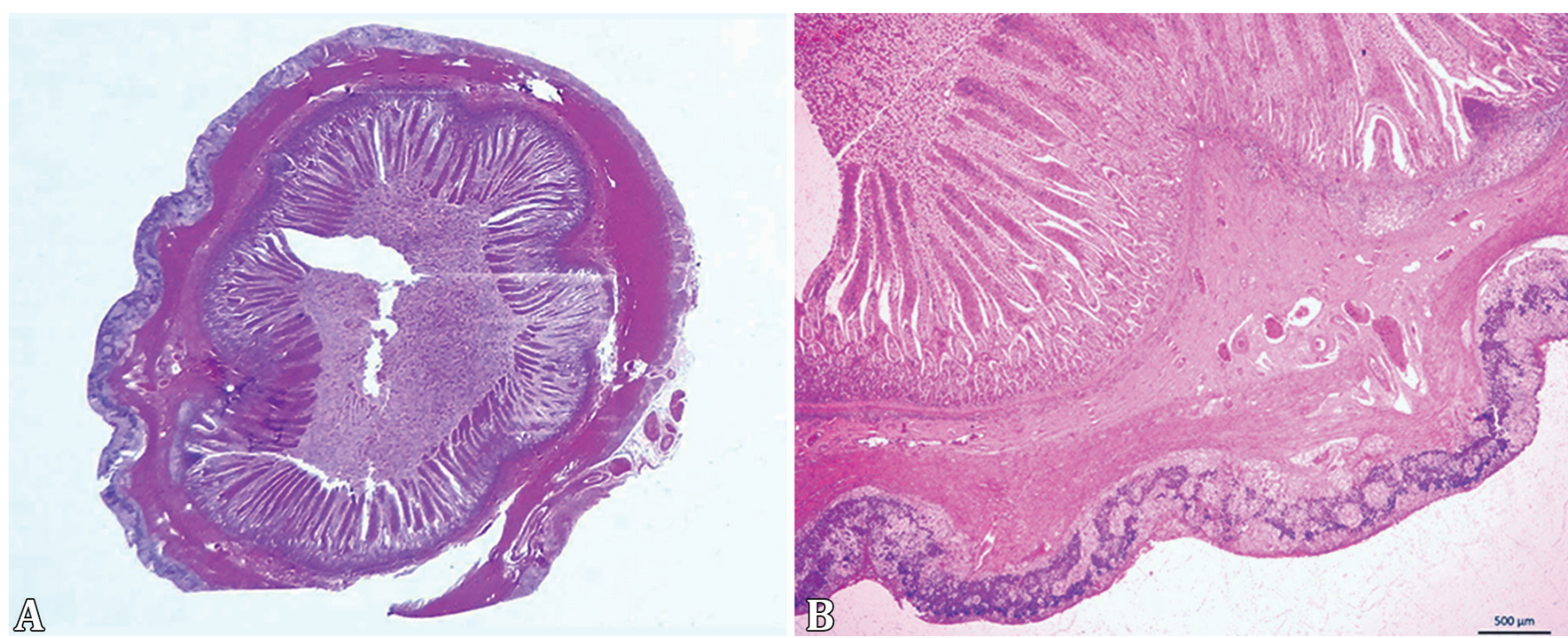

Fig.4. Chronic kidney disease (CKD) in dogs. Uremic enteropathy. Multifocal to coalescent dystrophic mineralization accentuated in the serosa and outer (longitudinal) muscular layer. (A) Submacroscopic imaging and (B) small bowel photomicrograph. Dog 18, G3. HE, obj.5x. 
facial deformity, characterized by increased volume of these bones. In the oral cavity, there was misalignment and tooth mobility, as well as malocclusion, absence of dentin in the upper canines, exposure of the dental pulp, and wear of the incisor teeth. Histopathology revealed marked fibroplasia with replacement of bone trabeculae, osteopenia, thin, fragmented and disconnected bone trabeculae, numerous osteoclasts, and Howship's lacunae (bone resorption).

\section{DISCUSSION}

Changes in mineral metabolism are frequent in dogs with chronic kidney disease (CKD) (Brito Galvão et al. 2013). In fact, in this study, ionized hypocalcemia was the most frequently observed mineral biochemical change. According to Schenck et al. (2007), less than $10 \%$ of dogs with CKD have high serum ionized calcium (Cai) concentrations, which corroborates the findings of this study, since none of the 40 dogs assessed presented ionized hypercalcemia. Cortadellas et al. (2010) also reported reduction intotal calcium (Cat) and Cai in dogs with severe azotemia. It is worth noting that these authors did not observe significant difference in Cat concentrations in healthy and CKD dogs, and none of the dogs they evaluated presented ionized hypercalcemia. Regarding the decrease in Cai concentration, the same was observed in cats in the last stage of the disease, whereas the average concentrations remained within normality during all stages (Barber \& Elliott 1998).

It is worth remembering that in CKD, Cat is useless in predicting the concentration of Cai, being fundamental to the measurement of the ionized fraction (Martinez \& Carvalho 2010). Ionized calcium should be measured directly and, in cases of hyperparathyroidism, kidney disease and hypo- and hyperproteinemia, the measurement and interpretation of the ionized fraction have been superior to the measurement of serum corrected calcium (Cac) (Giovaninni 2015). The correction of serum concentrations concerning serum albumin or total protein concentration is relevant for an adequate diagnostic interpretation, because the degree of mineral-protein binding is significant (80-90\% of serum calcium) (Schenck et al. 2007).

Hyperphosphatemia resulting from phosphorus retention due to progressive reduction in the glomerular filtration rate (GFR) (Geddes et al. 2013) was the second most frequent change in mineral metabolism observed in this study. Such abnormality is frequent since the early stages of CKD, and has a direct correlation with the worsening of azotemia, as it intensifies with the loss of nephrons, which was observed in this study, as well as in felines and humans (Elliott \& Barber 1998, Lazaretti et al. 2006, Cortadellas et al. 2010, Martinez \& Carvalho 2010, Giovaninni et al. 2013, Queiroz 2015, Valencia \& Arango 2015).

Hyperphosphatemia can result in secondary renal hyperparathyroidism (SRHPT), a common complication of CKD, as well as in soft tissue mineralization and CKD progression (Giovaninni 2015, Foster 2016). In this study, the increase in PTH levels (73.3\%) was considerably higher than the frequency of dogs with hyperphosphatemia (26.6\%) in G1, which may be explained by the corrective effect of SRHPT in the early stages of CKD, which leads to high PTH concentrations and induces phosphaturia and maintenance of serum phosphorus levels. In dogs and cats with end-stage CKD (moderate to severe azotemia), such usual compensatory mechanisms often fail to prevent hyperphosphatemia (Alfrey 2004, Polzin 2011, Davis
2015). In the present study, all dogs with hyperphosphatemia already had high PTH concentrations. Cortadellas et al. (2010) demonstrated that, in dogs with CKD, SRHPT is frequent and may even be present at stage 1 of the disease, suggesting that reduced renal phosphorus excretion and, consequently, serum retention would start at the earliest stages of CKD. Giovaninni et al. (2013) also found increased phosphorus and PTH concentrations in cats with mild azotemia.

Most lesions resulting from uremic syndrome are of renal origin and are mainly attributed to tubulointerstitial nephritis, renal infarction, granulomatous nephritis, glomerulonephritis and acute tubular necrosis, or to associations between these lesions (Dantas \& Kommers 1997, Inkelmann et al. 2012). The type and distribution of extrarenal uremia lesions found in the 16 autopsied dogs, including the frequent dystrophic mineralization observed in various organs and soft tissues, were similar to those described in the literature in cases of uremic syndrome (Cheville 1979, Dantas \& Kommers 1997, Peters et al. 2005, Silveira et al. 2015, D’Ávila et al. 2016), except for the uremic enteropathy with severe multifocal dystrophic mineralization found in one dog. Macroscopically, this lesion drew attention because it is an atypical case of intestinal mineralization, mainly due to the severity and multifocal distribution in the small intestine - dozens of whitish, irregular and firm plaques measuring up to $4.0 \times 1.6 \mathrm{~cm}$, thus never described in dogs with uremic syndrome. Cianciolo \& Mohr (2015) pointed out that intestinal lesions have lower intensity and frequency than those found in the stomach of dogs with CKD, and that intestinal mineralization has not been described in uremic dogs. However, this lesion has been reported in two dogs with $\mathrm{CKD}$, being described in the mucosa and sub-mucosa and in the muscle vessels of one animal (Dantas \& Kommers 1997), and as mild and located in the small intestine of the other (Silveira et al. 2015).

Some considerations should be made on the vascular mineralization found in the kidneys. At histopathologic examination, mineralization foci were more frequent in renal tubules, small vessel wall, glomeruli, and Bowman's capsule, in decreasing order of prevalence; however, such vascular mineralization has not been described in previous studies, although interstitial fibrosis, interstitial nephritis, tubular atrophy, tubular cell mineralization, and glomerulosclerosis were frequent (McLeland et al. 2014, D’Ávila et al. 2016); these lesions were attributed to prolonged uremia. In contrast, Newman (2013) reported that vessel calcification, tubular basement membranes, Bowman's capsule, and degenerate tubular epithelium are common in fibrotic kidneys because of changes in CKD-associated calcium and phosphorus metabolism.

In this study, coagulation necrosis and cardiac dystrophic mineralization were observed in $43.7 \%$ and $25 \%$ of dogs, respectively. Lesions in cardiomyocytes of this nature, as well as changes in cardiac vessels in chronic nephropathic dogs with uremia, have recently been reported to be much more frequent than those mentioned in the literature, and have been attributed to long-term uremia and/or hemodynamic and metabolic changes occurring in type IV cardiorenal syndrome (D’Ávila et al. 2016). In the present study, these vascular lesions were not observed probably due to the limited number of cardiac fragments evaluated. In contrast, atherosclerosis was observed in $75 \%$ of the necropsied dogs - a vascular lesion previously described in uremic dogs (Dantas \& Kommers 
1997). Observation of these degenerative, inflammatory or necrotic lesions in uremic dogs reinforces the hypothesis that a dystrophic lesion precedes mineralization.

Mineral metabolism-related injuries such as parathyroid hyperplasia and fibrous osteodystrophy are less frequent, and occur in cases of extreme CKD (Dantas \& Kommers 1997, Silveira et al. 2015, Foster 2016); however, it is crucial to consider that bones are not often submitted to routine histologic examination, which makes the diagnosis of this change difficult in early stages of disease, snd can be underestimated in uremic dogs since clinical manifestations range from mild, focal or generalized bone loss to fibrous osteodystrophy (Davis 2015). In this study, fibrous osteodystrophy occurred in a 5-month-old pup, and was due to juvenile nephropathy. Interestingly, the primary renal disease with SRHPT (mineralization disorder) bone deformities due to the classic increase in surface volume was mistaken for the previous clinical examination of bone malformation. This error underscores the importance of knowledge about the interactions that occur between two or more systems in some diseases.

In the present study, the absence of ionized hypercalcemia shows that calcemia does not play a significant role in the tissue mineralization of uremic dogs, even in face of the possibility that ionized hypercalcemia may have been transient and, therefore, not detected in the exams performed. This is because tissue mineralization is a chronic lesion that occurs over the course of weeks or months. It is important to remember that transient hypercalcemia has previously been demonstrated in cases of experimental poisoning by calcinogenic plants (containing vitamin D analogs) in cattle (Dobereiner et al. 1971) and sheep (Riet-Correa et al. 1993). Only a slight increase in calcemia was observed within the first 24 and 48 hours after the administration of these plants (Dobereiner et al. 1971, Riet-Correa et al. 1993). Similarly, these findings demonstrated that the tissue mineralization observed in animals intoxicated by these plants also has no direct correlation with hypercalcemia (Peixoto et al. 2012), as they have been mistakenly disseminated in textbooks, which are based on the Virchow's classification, previously questioned by Seifert \& von Hentig (1967). Nevertheless, Peixoto et al. (2012) recently proposed that hypervitaminosis D-induced mineralization should be more appropriately termed metaplastic mineralization.

It has previously been mentioned that animals with CPP $>60-70 \mathrm{mg}^{2} / \mathrm{dl}^{2}$ present higher risk of developing soft tissue mineralization, although these high concentrations are likely to persist for weeks and months (McLeland et al. 2014, Foster 2016). Additionally, Peters et al. (2005) correlated the occurrence of gastric mineralization in dogs with CKD with high CPP values, and stated that dogs with CPP $>60-70 \mathrm{mg}^{2} / \mathrm{dl}^{2}$ would present higher risk of developing tissue and vascular mineralization, and that these would be of the metastatic type. Importantly, in the present study, although CPP was elevated mainly in severely azotemic dogs, this increase was attributed to frequent hyperphosphatemia rather than to ionized hypercalcemia (absent all dogs). Other studies have also suggested or attributed soft tissue mineralization to changes in serum calcium and phosphorus values, but they did not evaluate serum mineral concentrations (McLeland et al. 2014, Silveira et al. 2015).

It should also be noted that the 15 dogs that developed tissue mineralization identified in the necroscopic and histopathologic examinations presented CPP values $>70 \mathrm{mg}^{2} / \mathrm{dl}^{2}$ and ionic hypocalcemia, regardless of the degree of azotemia. McLeland et al. (2014) found that the administration of phosphorus chelators in cats with CKD - to correct hyperphosphatemia - did not interfere with the occurrence of mineralization, which once again reinforces the hypothesis that mineralization is dystrophic. Additionally, this hypothesis also corroborates the biochemical findings of the dog that developed fibrous osteodystrophy, which although having suffered extreme bone calcium resorption due to SRHPT in an attempt to correct calcemia (Polzin 2011, Brito Galvão et al. 2013), still presented ionized hypocalcemia with marked CPP increase caused by hyperphosphatemia.

Indeed, according to Serakides (2011), since nephropathy is invariably irreversible and fatal, in cases of SRHPT there is no recovery of bone injury and, consequently, the plasma condition of hyperphosphatemia and hypocalcemia is perpetuated. Thus, the data described herein show, in a substantiated manner, that hypercalcemia is not a requirement for soft tissue mineralization in dogs with CKD at different stages of azotemia.

We believe, however, that the association between CPP increase and tissue mineralization verified by other authors (Peters et al. 2005, McLeland et al. 2014, Foster 2016) is mistaken. What happens is that dogs in more advanced stages of CKD (renal failure) have higher hyperphosphatemia, which increases CPP. We believe that the most appropriate association would be between the occurrence of vascular and/or tissue lesions secondary to uremia and the development of tissue mineralization, as verified and discussed in this study. It is worth remembering that these vascular and/or tissue lesions are chronic, and more frequent and severe in more advanced stages of CKD (renal failure), which strengthens the idea that mineralization observed in dogs with CKD requires previous injury and is, therefore, considered dystrophic.

In conclusion, the laboratory (azotemia, hypocalcemia, hyperphosphatemia, and CPP) and histopathologic data described herein, especially concerning tissue and vascular mineralization, which occurs in association with previous degenerative-necrotic lesions (essential requirement for dystrophic mineralization) in the absence of hypercalcemia (essential requirement for metastatic mineralization) in dogs with CKD associated with information available in the principal studies on this subject (Dantas \& Kommers 1997, Peters et al. 2005, Vlleet \& Ferrans 2009, Silveira et al. 2015, D'Ávila et al. 2016), provide subsidies that assist with clarifying inconsistencies found in the literature. It is noteworthy that, although the mineralization observed in uremic dogs presents systemic distribution - a characteristic of metastatic mineralization - this is because uremia occurs with multisystemic lesions and, therefore, mineralization occurs on these multiple previous lesions.

\section{CONCLUSION}

Organ and tissue mineralization in dogs with chronic kidney disease is preceded by degenerative/necrotic vascular and tissue damage resulting from toxins accumulated in the bloodstream, and which occur in the absence of hypercalcemia. Therefore, conceptually, mineralization that occurs in uremic dogs should be considered dystrophic.

Conflict of interest.- The authors have no conflicts of interest to declare. 


\section{REFERENCES}

Alfrey A.C. 2004. The role of abnormal phosphorus metabolism in the progression of chronic kidney disease and metastatic calcification. Kidney Int. 6(90):13-17. <http://dx.doi.org/10.1111/j.1523-1755.2004.09003. $\mathrm{x}><$ PMid:15296502>

Barber P.J. \& Elliott J. 1998. Feline chronic renal failure: calcium homeostasis in 80 cases diagnosed between 1992 and 1995. J. Small Anim. Pract. 39(3):108-116. <http://dx.doi.org/10.1111/j.1748-5827.1998.tb03613. $\mathrm{x}><$ PMid:9551377>

Brito Galvão J.F., Nagode L.A., Schenck P.A. \& Chew D.J. 2013. Calcitriol, calcidiol, parathyroid hormone, and fibroblast growth factor-23 interactions in chronic kidney disease. J. Vet. Emerg. Crit. Care 23(2):134-162. <http:// dx.doi.org/10.1111/vec.12036> <PMid:23566108>

Cheville N.F. 1979. Uremic gastropathy in the dog. Vet. Pathol. 16(3):292-309. <http://dx.doi.org/10.1177/030098587901600303><PMid:442460>

Cheville N.F. 2004. Calcificação, p.29-54. In: Cheville N.F. (Ed.), Introdução a Patologia Veterinária. Roca, São Paulo.

Chew D.J. \& Meuten D.J. 1982. Disorders of calcium and phosphorus metabolism. Vet. Clin. N. Am., Small Anim. Pract. 12(3):411-438. <http:// dx.doi.org/10.1016/S0195-5616(82)50053-8><PMid:6983763>

Cianciolo R.E. \& Mohr F.C. 2015. Urinary system, p.377-463. In: Maxie G. (Ed.), Jubb, Kennedy and Palmer's Pathology of Domestic Animals. Vol 2. 6th ed. Elsevier, Missouri.

Confer A.W. \& Panciera R.J. 1998. Sistema urinário, p.228-265. In: Carlton W.W. \& McGavin M.D. (Eds), Patologia Veterinária Especial de Thomson. $2^{\underline{a}}$ ed. Artmed, Porto Alegre.

Cortadellas 0., Fernandez Del Palacio M.J., Talavera J. \& Bayon A. 2010. Calcium and phosphorus homeostasis in dogs with spontaneous chronic kidney disease at different stages of severity. J. Vet. Intern. Med. 24(1):73-79. <http://dx.doi.org/10.1111/j.1939-1676.2009.0415.x><PMid:19925576>

D’Ávila M.S., França T.N., Peixoto P.V., Peixoto T.C., Santos A.M., Costa S.Z.R., Santos R.S., Gonçalves T. \& Nogueira V.A. 2016. Avaliações morfológica e imuno-histoquímica (Troponina C) de lesões cardíacas em cães com doença renal crônica. Revta Bras. Med. Vet. 38(2):128-138.

Dantas A.F.M. \& Kommers G.D. 1997. Lesões extra-renais de uremia em 72 cães. Ciência Rural 27(2):301-306. <http://dx.doi.org/10.1590/S010384781997000200022>

Davis E.M. 2015. Oral manifestations of chronic kidney disease and renal secondary hyperparathyroidism: a comparative review. J. Vet. Dent. 3(2):8798.<http://dx.doi.org/10.1177/089875641503200202><PMid:26415385>

Dobereiner J., Tokarnia C.H., Costa J.B.D., Campos J.L.E. \& Dayrell M.S. 1971. "Espichamento", intoxicação de bovinos por Solanum malacoxylon no Pantanal de Mato Grosso. Pesq. Agropec. Bras. 6:91-117.

Doerr K.A., Outerbridge C.A., White S.D., Kass P.H., Shiraki R., Lam A.T. \& Affolter V.K. 2013. Calcinosis cutis in dogs: histopathological and clinical analysis of 46 cases. Vet. Dermatol. 24(3):355-379, e78-e79. <http:// dx.doi.org/10.1111/vde.12026><PMid:23565978>

Elliott J. \& Barber P.J. 1998. Feline chronic renal failure: clinical findings in 80 cases diagnosed between 1992 and 1995. J. Small Anim. Pract. 39(2):78-85. <http://dx.doi.org/10.1111/j.1748-5827.1998.tb03598. x><PMid:9513888>

Foster J.D. 2016. Update on mineral and bone disorders in chronic kidney disease. Vet. Clin. N. Am., Small Anim. Pract. 46(6):1131-1149. <http:// dx.doi.org/10.1016/j.cvsm.2016.06.003><PMid:27436330>

Geddes R.F., Finch N.C., Syme H.M. \& Elliott J. 2013. The role of phosphorus in the pathophysiology of chronic kidney disease. J. Vet. Emerg. Crit. Care 23(2):122-133.<http://dx.doi.org/10.1111/vec.12032><PMid:23464730>

Giovaninni L.H. 2015. Cálcio e fósforo, p.935-943. In: Jericó M.M., Kogika M.M. \& Neto J.P.A. (Eds), Tratado de Medicina Interna de Cães e Gatos. Vol.2. Roca, Rio de Janeiro.
Giovaninni L.H., Kogika M.M., Lustoza M.D., Reche Junior A., Wirthl V.A.B.F., Simões D.M.N. \& Coelho B.M. 2013. Serum intact parathyroid hormone levels in cats with chronic kidney disease. Pesq. Vet. Bras. 33(2):229-235. <http://dx.doi.org/10.1590/S0100-736X2013000200015>

Inkelmann M.A., Kommers G.D., Trost M.E., Barros C.S.L., Fighera R.A., Irigoyen L.F. \& Silveira I.P. 2012. Lesões do sistema urinário em 1.063 cães. Pesq. Vet. Bras. 32(8):761-771. <http://dx.doi.org/10.1590/S0100736X2012000800015>

IRIS 2017. IRIS Staging of CKD. Available at <http://www.iris-kidney.com/ guidelines/staging.html> Accessed on Oct. 2, 2018.

Jones T.C., Hunt R.D. \& King N.W. 2000. Depósitos minerais e pigmentos, p.63-86 In: Jones T.C., Hunt R.D. \& King N.W. (Eds), Patologia Veterinária. 6a ed. Manole, Barueri.

Kilpatrick S., Gow A.G., Evans H. \& Mellanby R.J. 2015. Adrenocorticotrophic hormone causes an increase in cortisol, but not parathyroid hormone, in dogs. Res. Vet. Sci. 98:13-15. <http://dx.doi.org/10.1016/j.rvsc.2014.11.018> <PMid:25544698>

Lazaretti P., Kogika M.M., Hagiwara M.K., Lustoza M.D. \& Mirandola R.M.S. 2006. Concentração sérica de paratormônio intacto em cães com insuficiência renal crônica. Arq. Bras. Med. Vet. Zootec. 58(4):489-494. <http://dx.doi. org/10.1590/S0102-09352006000400006>

Martinez P.P. \& Carvalho M.B. 2010. Participação da excreção renal de cálcio, fósforo, sódio e potássio na homeostase em cães sadios e cães com doença renal crônica. Pesq. Vet. Bras. 30(10):868-876. <http://dx.doi.org/10.1590/ S0100-736X2010001000010>

McLeland S.M., Lunn K.F., Duncan C.G., Refsal K.R. \& Quimby J.M. 2014. Relationship among serum creatinine, serum gastrin, calciumphosphorus product, and uremic gastropathy in cats with chronic kidney disease. J. Vet. Intern. Med. 28(3):827-837. <http://dx.doi.org/10.1111/jvim.12342> $<$ PMid:24628683>

Newman S.J. 2013. O Sistema urinário, p.592-662. In: Zachary J.F. \& McGavin M.D. (Eds), Bases da Patologia em Veterinária. $5^{\mathrm{a}}$ ed. Elsevier, Rio de Janeiro.

Peixoto P.V., Klem M.A.P., França T.N. \& Nogueira V.A. 2012. Hipervitaminose D em animais. Pesq. Vet. Bras. 32(7):573-594. <http://dx.doi.org/10.1590/ S0100-736X2012000700001>

Peters R.M., Goldstein R.E., Erb H.N. \& Njaa B.L. 2005. Histopathologic features of canine uremic gastropathy: a retrospective study. J. Vet. Intern. Med. 19(3):315-320. <http://dx.doi.org/10.1111/j.1939-1676.2005.tb02700. $\mathrm{x}><$ PMid:15954544>

Polzin D.J. 2008. Diagnosing \& staging kidney disease in dogs and cats, 2008. Available at <www.chicagovma.org/wp-content/uploads/2014/06/ Nephrology-2008.pdf> Accessed on Oct. 3, 2018.

Polzin D.J. 2011. Chronic kidney disease in small animals. Vet. Clin. N. Am., Small Anim. Pract. 41(1):15-30. <http://dx.doi.org/10.1016/j. cvsm.2010.09.004><PMid:21251509>

Queiroz L.L. 2015. Abordagem diagnóstica e terapêutica de cães com doença renal crônica com ênfase na hiperfosfatemia. Master's Thesis, Universidade Federal de Goiás, Goiânia. 86p.

Riet-Correa F., Mendez M.D.C., Schild A.L. \& Petiz C.A. 1993. Enzootic calcinosis in sheep: experimental reproduction with Nierembergia veitchii (Solanaceae). Pesq. Vet. Bras. 13(1/2):21-24.

Romão Junior J.E. 2004. Doença renal crônica: definição, epidemiologia e classificação. J. Bras. Nefrol. 16(3):1-3.

Santos J.A. 1979. Aparelho urinário, p.47-80. In: Santos J.A. (Ed), Patologia Especial dos Animais Domésticos. $2^{\mathrm{a}}$ ed. Guanabara Koogan, Rio de Janeiro.

Schenck P.A., Chew D.J., Nagode L.A. \& Rosol T.J. 2007. Distúrbios relacionados ao cálcio: hiper e hipocalcemia, p.115-183. In: Dibartola S.P. (Ed.), Anormalidades de Fluidos, Eletrólitos e Equilíbrio Ácido-básico na Clínica de Pequenos Animais. 3aㅡ ed. Roca, São Paulo. 
Seifert G. \& von Hentig 0.1967. Histochemische und elektronisch-optische Befunde zur Pathogenese der experimentellen Hautkalzinose. Beitrag Pathol. Anatom. 135(1):75-91. <PMid:4232447>

Serakides R. 2011. Sistema urinário, p.291-336. In: Santos R.L. \& Alessi A.C. (Eds), Patologia Veterinária. Roca, São Paulo.

Silveira I.P., Inkelmann M.A., Tochetto C., Rosa F.B., Fighera R.A., Irigoyen L.F. \& Kommers G.D. 2015. Epidemiologia e distribuição de lesões extrarrenais de uremia em 161 cães. Pesq. Vet. Bras. 35(4):562-568. <http://dx.doi. org/10.1590/S0100-2015000600013>

Valencia C.A.R. \& Arango J.V.A. 2015. Vitamin D (25(OH)D) in patients with chronic kidney disease stages 2-5. Colombia Med. 47(3):160-166.

Vlleet J.F.V. \& Ferrans V.J. 2009. Sistema cardiovascular, p.559-614. In: McGavin M.D. \& Zachary J.F. (Eds), Bases da Patologia em Veterinária. $4^{\mathrm{a}}$ ed. Elsevier, Rio de Janeiro. 